Bob Becking (Utrecht University and University of Pretoria)

\title{
PHOENICIAN SNAKES AND A PROPHETIC PARALLELISM: AN IMPLICATION FOR ZEPHANIAH 1:9 OF A RECENT DISCOVERY IN THE EGYPTIAN PYRAMID TEXTS ${ }^{1}$
}

\begin{abstract}
The parallelism in Zeph 1:9 is not prima facie clear: how can the act of jumping over the threshold be connected to the bringing of violence and deceit into the realm of the Temple? The discovery of early west Semitic lines in the Egyptian Pyramid Texts revealed a scenario in which a guarding deity protected the inner realm of the tomb against infiltrating serpents. In assuming that Zeph 1:9 refers to the presence of a guarding deity at the threshold, the jumpers can be seen as people wanting to avoid this guardian and hence as persons who were unwelcome in the temple.
\end{abstract}

\section{A PROBLEMATIC PARALLELISM}

In his announcement of the forthcoming and devastating Day of YHWH, the prophet Zephaniah indicates a specific group of people that will be judged. After having reproached the leading circles in Jerusalem for their political and religious trespasses, he announces:

And I will punish on that day all who leap over the threshold,

Who fill the house of their lord with violence and deceit? (Zeph

A parallelism between v. $9 \mathrm{a}$ and v. $9 \mathrm{~b}$ can be assumed, as in many other prophetic and poetic texts. ${ }^{2}$ The connection between the two lines is, however, not prima facie clear. Although the words "threshold" and "house" belong to the same semantic domain, it is unclear what "leaping" has to do with "violence and deceit". The Peshitta has created a beautiful parallelism by rendering the Hebrew for "all who leap on the threshold" with "all who are robbers and plunderers", thus providing a clear parallel for "violence and deceit". In modern scholarship various proposals have

1 This study is an extended version of a paper read at the International Meeting of the Society of Biblical Literature, St Andrews, July 2013.

2 See, e.g., Collins (1978:228-244); Watson (1984:114-159); Berlin (1985); Korpel \& de Moor (1988:1-61); Kugel (1998); Verdonk (2005:231-244); Tsumura (2009:167-181). 
been formulated as to the character of this parallelism. Cheyne (1898:569) is willing to break the parallelism by construing the expression "all who leap over the threshold" as a concessive subordinate clause: "though they leap with scrupulous reverence ... yet they bring with them ... hands stained with cruelty and injustice". Elliger (1967:64) does not pay attention to the possibility of a parallel. ${ }^{4}$ Van der Woude (1978:96) assumes that the undiscriminating adoption of foreign religious practices by the leading classes of Jerusalem must have been construed as contempt and offence of YHWH. ${ }^{5}$ Seybold $(1985: 25-28,109)$ construes v. $9 \mathrm{~b}$ as a later, moralizing addition. Ben Zvi (1994:95-102) is of the opinion that the text of Zeph 1:9 is intentionally ambiguous. Berlin (1994:79-80) does not see a clear connection between the two lines. Sweeney (2003:88) sees the following connection: he construes "all who cross over the threshold" to be priests who instead of performing acts of righteousness and holiness, fill God's house with violence and deceit. ${ }^{6}$

These proposals, however, are not convincing. They do not give an answer to the question of balance between the two parts of the verse. For a clear parallelism both cola have to express the same subject matter. The second colon reiterates the topic of the first either by using parallel words and phrases or by presenting a clear parallel concept (Watson 1984:114159; Berlin 1985; Kugel 1998). These elements seem to be absent in the proposals mentioned above.

\section{RELIGIOUSLY JUMPING OVER THE THRESHOLD}

A first step on a way to a more compelling view on the parallelism between the two lines in Zeph 1:9 would be to focus on the expression

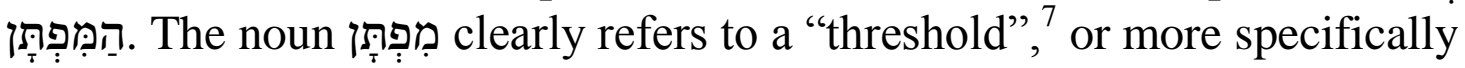
"the space under the threshold-stone" (Zwickel 1973:25-27; Porter 1993:65-75; Hagedorn 2012:141-142). Gerleman - who still thought that מִפָּתָן was some sort of a postament - has tried to explain this expression

3 For the syntax of such clauses, see, e.g., König \& Siemund (2000:342-360).

4 See also Edler (1984:124-132); Vlaardingerbroek (1999:87-90); House (1989:63, 70, 98); Robertson (1990:277-278).

5 In a similar way Irsigler (1977:241-42); Snyman (2000:89-102); Irsigler (2002:144); Udoekpo (2010:277).

6 A comparable view holds Hagedorn (2012:143).

7 As is accepted by almost all interpreters; the view of Winckler (1905:381-384), adapted by Gerleman (1942:8-14); Sabottka (1972:36-44); that מִפְת refer to a rostrum that can be climbed is now generally abandoned. 
by comparing the Hebrew verb דָָּ with Arabic darağa, "to mound". In his view, the expression would refer to a cultic act in which a priest was climbing a platform (Gerleman 1942:9; Udoekpo 2010:277). It is, however, much more convincing to make a connection with the report on Philistine priests who would not dare to tread the threshold of the temple of Dagon in Ashdod (1 Sam 5:5). ${ }^{8}$ In the light of that comparison, Zeph $1: 9$ could easily be seen as referring to the act of jumping over the threshold. This act would then represent the more folkloristic or traditional side of religion. It was fuelled by fear for threatening demons supposedly dwelling under that threshold. ${ }^{9}$ Extra-biblical evidence for this reasonable proposal, however, has until recently not been found (Uehlinger 1996:58). The closest parallel comes from a passage in the Hittite text, $K U B 11.17$ Rev. iv:6-11, where the king has to stamp on the threshold when leaving the sanctuary to demonstrate his power over the demonic world. Although this text shares the conceptual model of Zeph $1: 9$, it could not be seen as a parallel.

\section{SEMITIC SERPENT SPELLS IN THE EGYPTIAN PYRAMID TEXTS}

The next step would be to pay attention to a recent discovery in the Egyptian Pyramid Texts. Pyramid Texts are collections of religious apophthegms that in the period of the Old Kingdom were engraved on the walls of the tombs of the Pharaohs (Allen 2005:1-14; Hays 2012:69-289). The amount and the order of spells and proverbs vary from tomb to tomb. It can be assumed that the writers at the Egyptian court had a broad arsenal of texts at their disposal. The selection of sayings was - as can be assumed - connected to the character of the deceased. Egyptologists generally accept that the Pyramid Texts as we now know them go back to oral traditions that reach beyond the period of the construction of the first

8 This connection has already been seen by the Targum which reads in Zeph 1:9: בנמוסי פלשתאי , "according to the customs of the Philistines". See Cathcart \& Gordon (1989:166); Ho (1997:218-222).

9 See especially Donner (1970:42-55). His view is now widely adopted, see Van der Woude (1978:96); Edler (1984:129-31); Seybold (1985:27-28); Schroer (1987:169-77); Deissler (1988:240); Albertz (1992:304); Berlin (1994:79-80); Irsigler (2002:142-144); Sweeney (2003:85-88); Norin (2002:75-100); Wöhrle (2006:201); Jin-Hi (2006:24); Hagedorn (2012:141-142). Criticism of this view is uttered by Ben Zvi (1994:95-102), who, however, did not present an alternative interpretation. Cogan (1993:411) also has his doubts. 
pyramids (Baines 2004:15-41; Steiner 2011:1-3). The Pyramid Texts have their function to safeguard the journey of the deceased Pharaoh to the Heavenly Egypt. Within the Pyramid Texts different kinds of sayings occur. Next to hymns and litanies, texts are found that present in a dramatic way the mythological battle - with political consequences between Horus and Seth (Tobin 1993:93-110; Meurer 2002). The greatest section in the Pyramid Texts, however, is formed by eulogies and other lines that praise the deceased. Finally, in this corpus magical spells are to be found that aim at shielding the Pharaoh on his journey from all sorts of evil, especially from attacks by snakes. ${ }^{10}$

The serpent spells, however, contain lines, that are inscrutable even for a seasoned Egyptologist. They read like abracadabra. Sethe labels these lines as magic words that are difficult to interpret and look like hocus pocus (Leitz 1996:385). Faulkner (1969:56) and Altenmüller (1972:258) construe these lines as untranslatable from first to last. Mathieu (2002:191) is of the opinion that in some of these lines a magical palindrome is detectable. Allen (2005:5-55) offers a translation that is, however, both puzzling and incomprehensible. Hays (2012:278) states that he "does not possess the skills to make a guess as to the original language of the voces magicae".

Steiner (2011) - who previously recognized with Charles Nims a Semitic text in the Demotic Papyrus Amherst 63 containing among others an extra-biblical version of Ps 20 (Nims \& Steiner 1983:261-274) - has made plausible that these passages in the serpent spells should be construed as Semitic texts. Or to be more precise: the serpent spells contain in his view the oldest West Semitic texts known. They precede the earliest Ugaritic inscriptions by a millennium and are a few centuries older than the earliest known East Semitic, Akkadian texts. It should be noted that his view is not unchallenged among Egyptologists. ${ }^{11}$ From the point of view of a Semitist, his proposal, however, makes sense. This implies that I offer my ideas with some caution and I am prepared to reiterate in case scholars will be able to falsify Steiner's proposal. Although I share both the caution and the warning that we do not have West Semitic texts contemporary to the serpent spells as expressed by

10 The standard edition of the Pyramid Texts is to be found in Sethe (1908); for a recent translation, see Meurer (2002:269-315); and Allen (2005).

11 Schneider and Sapir posted criticism on some details at the ANE-list. See http://www.talkingpyramids.com/serpent-spells-2/. Their criticism was, however, never published. 
Morgenstern (2012:450-451) in his review of Steiner's book, I nevertheless think that we should accept Steiner's proposal until proven incorrect. The criticism by Hays (2012:276-280), looks impressive but concentrates on the fact that Steiner did not read the serpent spells in the wider context of the Pyramid-texts. Hays does not offer criticism at the level of linguistics. Breyer (2013:141-146) makes a whole set of valuable philological remarks that cast doubt on Steiner's thesis, but do not falsify it.

\section{TRANSLATION}

I here offer my translation of the pertinent passages in the serpent spells, based on the interpretation of Steiner. Lines in Semitic are presented in SMALL CAPS.

PT 232- $238^{12}$

$\S 236$ a Come, poison! Come, poison!

Look, poison! Look, poison!

§236b You, whose mother is Rirr-rîr! $!^{13}$

You, whose mother is Rīr-rīr!

Look, poison! Look, poison!

\$236c Be washed away from me, o (poison of a) foreign land!

Do not ignore me!

\$237a Fall, o serpent that came forth from the earth!

Fall, o glow that came forth from the abyss!

§237b Fall down!

Crawl away!

\$238a A gaze is upon you, o you that moves on your belly.

Get back on your spine, o you that dwells in the naut-bush.

12 Different systems for numbering the lines in the Pyramid Texts exist. See Allen (2005:3-5); and Hays (2012).

13 The spells hint at a being indicated with 333, which is to be seen as a rendition in hieroglyphs for three 'älephs. The 'äleph indicates the sound /r/. In fact, $r r r$ should be read. Steiner (2011:15-22) construes this word as the personal name of a goddess Rīr-rīr. She should be seen as a two-headed serpent goddess with heads on both ends of the body who could be called upon in case of distress. Her name signifies something like "Spittle-Spittle". Cf. the Semitic noun "spittle", in 1 Sam 21:14 and Job 6:6. It refers to the phenomenon that snakepoison is spit out through spittle. The goddess, however, safeguards against threatening serpents. 
\$238b Retreat before her

Who jubilates with both her faces.

\$239a UTTERANCE $(k a w w u)^{14}$ OF RĪR-RĪR, THE MOTHER-OF LIFE, THE MOTHER-OF LIFE. ${ }^{15}$

\$239b You have had intercourse

with the two female guardians at the threshold of the door. TURN ASIDE, O MY BELOVED, O LION.

$\$ 240$ HIS UTTERANCE: "COME, COME TO MY HOUSE!"

"Cord" son of "Mother's milk" is this your name.

\$241a The spittle has come to nothing;

that which is in the dust, has fled into the house of his mother.

\$241b Monster, lie down.

$\$ 242 \mathrm{a}$ The bread of your father is for you, you whose attack was unsuccessful.

\$242b Your own bread of your father is for you, you whose attack was unsuccessful.

§242c The gold of jubilation, Hadad, ${ }^{16}$ your bull, the esteemed one against whom this had been undertaken.

PT 281-282

\$422a HIS WHISPERING, THE UTTERANCE OF HIS SPELL:

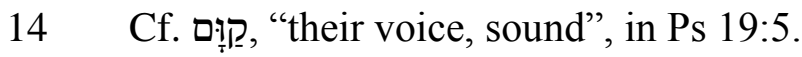

15 Steiner (2011:28) translates im ḥw with "mother snake". In view of the distant

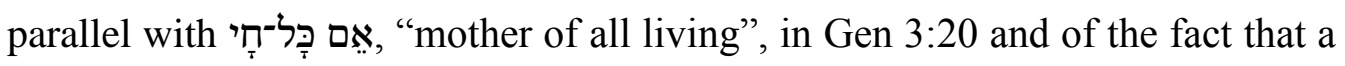
meaning "snake, serpent" for * $h w$, is only attested in Aramaic (hewyāh) and not in other west Semitic languages, a rendition with "mother of life", is more probable.

16 The serpent spells twice mention a deity that is indicated in the text as $H^{\prime} y$ - $t 3 w$. Steiner (2012:38), construes this morpheme as an epithet that he quite literally renders with "The One that Appears in Flame". The context, however, makes clear that this deity possesses power over the "Byblites", since he commands these threatening serpents to retreat. Steiner is correct that $H^{\prime} y$ - $t 3 w$ would refer to an ancient Byblite deity. I would like to go one step further by offering a proposal for identification of $H^{\mathfrak{c}} y$-t3w. In my view, this name refers to the West Semitic storm and thunder god, Hadad or Haddu. Concerning this deity, see Greenfield (1999:377-382); and Green (2003). Texts from Ugarit mention Hadad/Baal as a god battling against serpents. See $\mathrm{KTU}^{3}$ 1.5:1-2; 1.82:7-8. 
"RĪR-RĪR IS IN ME".

\$422b SEE MY MOUTHS, SEE MY VULVAE, MY MOUTHS, SEE MY VULVAE.

\$422c WHO AM I?

RĪR-RĪR, FRAGRANT PERFUME FOR THE NOSE, AM I.

§422d Go! Go!

$N^{\prime} y$-snake! $N^{\prime} y$ - snake!

$\$ 423 \mathrm{a} \quad \mathrm{O}$, (snake of) this foreign land,

like the mouth of a vulture against me!

This is (the true nature) of your attack.

$\S 423 \mathrm{~b} \quad \mathrm{O}$, (snake of) this foreign land,

like the mouth of a vulture against me,

(you are) a subject to the Gold of Jubilation.

\$423c Hadad and Jubilation!

That is your bull, the esteemed one

against whom this had been undertaken.

PT 286-287

\$427a HURRY AWAY FROM RĪR-RĪR,

WHOSE HANDS BRING DEATH.

\$427b The Byblites have crawled back.

$\mathrm{O}$, praised one of the Red Crowns.

\$427c Rīr-rīr of the sea, Rīr-rīr of the sea.

$\mathrm{O}$, praised one of the Red Crowns,

$\$ 427 \mathrm{~d} \quad$ may you praise my name!

$\S 428 \mathrm{a} \quad \mathrm{O}$, fugitive from its mother!

O, fugitive from its mother!

$\$ 428$ b You really are a fugitive!

You really are a fugitive!

O lion, disappear!

\section{RITR-RIRR VERSUS PHOENICIAN SNAKES}

It seems clear that a snake called Rīr-rīr is protecting the tomb against evil powers who are embodied as snakes from a foreign land ( $\$ 423 \mathrm{a})$. In $\$ 427 \mathrm{a}$, they are depicted as $k b n w$. Allen (2005:53) already remarked that the Egyptian noun kbnw, "Byblites", does not refer to inhabitants of that Phoenician city, but stands metonymically for snakes or serpents from that harbour city. Steiner (2011:10-14) correctly noted that already in the fourth millennium BCE trade contacts between Egypt and the Levantine 
harbours had developed. ${ }^{17}$ The Byblite serpent would have come as stowaways on ships to Egypt. These Byblites are also indicated as "(serpent of) a foreign land". The presence of Byblite serpents in Egypt elucidates the use of west Semitic in the serpent spells: one should whisper at a foreign snake in its own mother's tongue.

\section{PROTOTYPICAL SCENARIO}

At first sight, the lines in these sections are only loosely connected (Hays 2012:276-80). A closer inspection, however, reveals that the sections are the expression of a very specific prototypical scenario. This idea refers to a schematic recapitulation of a series of connected acts that form the basis of all sorts of epic tales, in literary form as well as in movies (Van Wolde (2010:54-60). The scenario that is expressed by the lines just translated from the Pyramid texts can be summarized in the following stages:

(1) One or more serpents want to enter a forbidden space;

(2) At the threshold they are waylaid by a guard who is in the service of the master of that house;

(3) The guard executes acts to hinder the entrance;

(4) In case the serpents do enter the forbidden realm, they are confronted with a series of spells;

(5) The serpents crawl back; and

(6) they move on their back through the dust and spit their poison into a hole in the earth.

This is a scenario that resembles the scenarios that are at the background of many ancient Near Eastern tales ${ }^{18}$ and biblical stories that relate the defence against threatening and sometimes demonic danger.

The text provides a mechanism that organizes order on two levels. On the one hand, it safeguards the deceased on his journey to the land of no return. On the other hand, it safeguards the Egyptian society. The death of a Pharaoh had always been a tempus nefas: a threatening period for the order in the community. The texts also govern human conduct. Nobody is allowed just to enter in the silent realm of the tomb. This institution is a hint for possible rebels not to disturb the peace of the country. Next to that

17 See also Joffe (2000:113-123); Kansa (2001).

18 See, e.g., some Sumerian texts in Krebernik (1984), the Ugaritic text, $\mathrm{KTU}^{3}$ 1.100, and an Aramaic scorpion spell (Steiner 2001:259-268). 
it should be noted that Rìr-rīr is positioned at the threshold of the pyramid. Such a threshold marks the transition from "outside" to "inside" and should be construed as liminal space. ${ }^{19}$ Here Rīr-rīr functions as a "doorkeeper" defending the peace in tomb and country as it is in continuous threat at the liminal threshold.

\section{A SIDE STEP: PS 24}

Over fifty years ago, Koch argued that a set of texts from the Hebrew Bible would contain the remnants of a "ritual for the entrance to the temple" (Koch 1961:45-60). Pss 15 and 24, Isa 33, Mic 6 would contain reflections of this liturgy. I will not discuss the merits of Koch's proposal in detail here. I will only take over his assumption that these texts refer to a preferred moral behaviour on the side of those who are allowed to enter the holy precinct. The morality is connected to the ethos expressed in the Decalogue. A programmatic text is Ps 24:3-4:

Who may ascend the mountain of YHWH?

Who may stand in his holy place?

The one who has clean hands and a pure heart, who does not trust in an idol

or swear by a false god (Botha 2009:535-553).

This implies that the liminal space on the threshold of the temple may not be crossed by deceitful people. I will come back to this point in my remarks on Zeph 1:9.

\section{ZEPH 1:9 AND STAGE 2 OF THE PROTOTYPICAL SCENARIO}

In my opinion, the religious ritual of leaping over the threshold in Zeph 1:9 can be connected to Stage 2 of the supposed scenario. At the threshold of the tomb of the Pharaoh, a serpent-goddess was present protecting and safeguarding the inner realm of the pyramid. The two female guardians in $\$ 239 \mathrm{~b}$ refer to the one goddess Rīr-rìr. Supposedly, Rīr-rīr not only was seen as a two-headed animal but also as having genitals on both ends of her body, as can be inferred from $\$ 422 b$. Her having intercourse with the threatening serpents should be seen as a functional act. As doorkeeper she guarded over the first defence line against the Byblite or Phoenician

19 On the religious function of the threshold in the ancient Near East, see Hartenstein (1997:116-122); and Berlejung (1998:27-28). An abundance of literature exists on the anthropological concept of liminality. See, e.g., van Gennep (1960); Girard (1972); and Douglas (1984). 
snakes. The aim of her copulating with the intruders is to bring the penetrating serpents into a dependent position, making a second defensive line possible.

Reading Zeph 1:9 from the implied prototypical scenario designed above leads to the following interpretative proposal. "Those who leap over the threshold" could be construed as a group of people wanting to enter the realm of the temple. This space, however, is forbidden territory for them. In the preceding verses in the book of Zephaniah, its author has outlined why on the forthcoming Day of YHWH inhabitants of Jerusalem will be devoured. The immoral and illicit conduct of the elite of the city has, in the opinion of the author, estranged them from God. V. 9 adds another set of evildoers to this catalogue. In my opinion, "jumping over the threshold of the temple in Jerusalem" is seen as act of avoiding a confrontation with a guardian deity. This implies that the divine being at the gate should not be seen as a demon, but rather as a safeguarding divine being defending as a doorkeeper the liminal space at the threshold of the temple.

This interpretation also provides clarity in the parallelism with v. $9 \mathrm{~b}$. "Those who leap over the threshold" could be construed as persons who, for reasons outlined in Zeph 1, are not allowed to enter the sacred realm of the temple. The reason for the fact that they are not welcome is underscored by v. $9 \mathrm{~b}$. As a result of their moral and religious conduct, they will bring violence and deceit into the temple in a similar way as they have brought violence and destruction to the city of Jerusalem. This interpretation connects the text of Zeph 1:9 with the ethos demanded for those who would enter the temple in Pss 15 and 24. This interpretation supplies a clear parallelism at the level of concept in v. $9 .{ }^{20}$ In addition, this interpretation might supply a distant parallel between Zeph 1:9 and a line in a Hittite instruction to priests and temple officials:

Neither pig nor dog is ever to cross the threshold (of the temple). ${ }^{21}$

By their illicit conduct, the elite of Jerusalem have rendered themselves as unfit for the temple as unclean animals were in ancient Hattushas.

20 As an implication, I would propose, with Nel (1989:155-167), not to see Zeph $1: 8-9$ as the result of a complex redaction-historical process; pace Edler (1984); Seybold (1985:25-28); Ben Zvi (1999:232-261); Neef (1999:530-546); Wöhrle (2006:199-205); Hagedorn (2012:141-143).

$21 \quad$ KUB 13.4 = CTH 264 iii 55-83. See Moyer (1981); and Collins (2006:156-57). 


\section{BIBLIOGRAPHY}

Albertz, R 1992. Religionsgeschichte Israels in alttestamentlicher Zeit (GAT, 8/1-2). Göttingen: Vandenhoeck \& Ruprecht.

Altenmüller, H 1972. Die Texte zum Begräbnisritual in den Pyramiden des Alten Reiches (Ägyptologische Abhandlungen 24). Wiesbaden: Harrasowitz.

Allen, J P 2005. The Ancient Egyptian Pyramid Texts (Writings of the Ancient World 23). Atlanta: Scholars Press.

Baines, J 2004. Modelling Sources, Processes, and Locations of Early Mortuary Texts, in: Bickel, S \& Mathieu, B (eds). D'un monde à l'autre: Textes des Pyramides et Textes des Sarcophages (Bibliothèque d'Etude 139). Cairo: Institut Français d'Archéologie Orientale du Caire, 15-41.

Ben Zvi, E 1994. A Historical-Critical Study of The Book of Zephaniah (BZAW 198). Berlin: De Gruyter.

Ben Zvi, E 1999. A Deuteronomistic Redaction in/among "The Twelve". A Contribution from the Standpoint of the Books of Micah, Zephaniah and Obadiah, in: Schearing, L S \& McKenzie, S L (eds). Those Elusive Deuteronomists (JSOTSup 268). Sheffield: Sheffield Academic Press, 232-261.

Berlejung, A 1998. Die Theologie der Bilder: Herstellung und Einweihung von Kultbildern in Mesopotamien und die alttestamentliche Bilderpolemik (OBO 162). Freiburg / Göttingen: Universitätsverlag / Vandenhoeck \& Ruprecht.

Berlin, A 1985. The Dynamics of Biblical Parallelism. Bloomington: Indiana University Press.

Berlin, A 1994. Zephaniah: A New Translation with Introduction and Commentary (AB 25A). New York: Doubleday.

Botha, P J 2009. Answers Disguised as Questions: Rhetoric and Reasoning in Psalm 24. OTE 22, 535-553.

Breyer, F 2013. Zu den angeblich semitischen Schlangensprüchen der Pyramidentexte. OLZ 107, 141-146.

Cathcart K J \& Gordon, R P 1989. The Targum of the Minor Prophets (ArBib 14). Edinburgh: T \& T Clark.

Cheyne, T K 1898. Gleanings in Biblical Criticism and Geography. JQR 10, 565-583.

Cogan, M 1993. Judah under Assyrian Hegemony: A Reexamination of Imperialism and Religion. JBL 112, 403-414. 
Collins, B J 2006. Pigs at the Gate: Hittite Pig Sacrifice in its Eastern Mediterranean Context. JANER 6, 155-188.

Collins, T 1978. Line Forms in Hebrew Poetry. JSS 23, 228-244.

CTH = Catalogue des textes hittites. http://www.hethport.uni-wuerzburg.de/CTH/

Deissler, A 1988. Zwölf Propheten III: Zefanja, Haggai, Sacharia, Maleachi (Neue Echter Bibel AT). Würzburg: Echter Verlag.

Donner, H 1970. Die Schwellenhüpfer: Beobachtungen zu Zephanja I, 8f. JSS 15, 4255.

Douglas, M 1984. Implicit Meanings: Essays in Anthropology. London: Routledge.

Edler, R 1984. Das Kerygma des Propheten Zefanja (Freiburger Theologische Studien 126). Freiburg: Herder Verlag.

Elliger, K 1967. Das Buch der Zwölf kleinen Propheten II: Die Propheten: Nahum, Habakuk, Zephanja, Haggai, Sacharja, Maleachi übersetzt und erklärt (ATD 25). 6th rev. ed. Gottingen: Vandenhoeck \& Ruprecht.

Faulkner, R O 1969. The Ancient Egyptian Pyramid Texts, Translated into English. Oxford: Oxford University Press.

Gerleman, G 1942. Zephanja Textkritisch und Literarisch Untersucht. Lund: Gleerup.

Girard, R 1972. La violence et le sacré. Paris: Grasset.

Green, A R W 2003. The Storm-God in the Ancient Near East (Biblical and Judaic Studies from the University of California 8). Winona Lake: Eisenbrauns.

Greenfield, J C 1999. Hadad, in: Van der Toorn, K, Becking, B \& Van der Horst, P W (eds). Dictionary of Deities and Demons in the Bible. 2nd rev. ed. Leiden: Brill, 377-382.

Hagedorn, A C 2012, Die Anderen im Spiegel: Israels Auseinandersetzung mit den Völkern in den Büchern Nahum, Zefanja, Obadja und Joel (BZAW 414). Berlin: De Gruyter.

Hays, H M 2012. The Organization of the Pyramid Texts: Typology and Disposition. 2 Vols (Probleme der Ägyptologie 31). Leiden: Brill.

Hartenstein, F 1997. Die Unzugänglichkeit Gottes im Heiligtum: Jesaja 6 und der Wohnort JHWHs in der Jerusalemer Kulttradition (WMANT 75). NeukirchenVluyn: Neukirchener Verlag.

Ho, A 1997. The Targum of Zephaniah: Manuscripts and Commentary (Studies in the Aramaic Interpretation of Scripture 7). Leiden: Brill. 
House, P R 1989. Zephaniah: A Prophetic Drama (Bible and Literature Series 16). Sheffield: Almond Press.

Irsigler, H 1977. Gottesgericht und Jahwetag. Die Komposition Zef 1,1-2,3, untersucht auf der Grundlage der Literarkritik des Zefanjabuches (ATS 3). St. Ottilien: EOS-Verlag.

Irsigler, H 2002. Zefanja. Übersetzt und ausgelegt (HThKAT). Freiburg: Herder Verlag.

Jin-Hi, W 2006. Kön 8, 1-9, 9: Literarische Analyse und theologische Interpretation (III). Theological Forum 46, 8-28.

Joffe, A H 2000. Egypt and Syro-Mesopotamia in the 4th Millennium: Implications of the New Chronology. Current Anthropology 41, 113-123.

Kansa, E C 2001. Smitten by Narmer: Ethnicity, Economy and Trade in the 4th Millennium BCE Egyptian Presence in the Southern Levant. PhD Dissertation Harvard University.

Koch, K 1961. Tempeleinlassliturgien und Dekaloge, in: Rendtorff, R \& Koch, K (eds). Studien zur Theologie der alttestamentlichen Überlieferungen. Festschrift G. von Rad zum 60. Geburtstag. Neukirchen: Neukirchener Verlag, 45-60.

König E \& Siemund P 2000. Causal and Concessive Clauses: Formal and Semantic Relations, in: Couper-Kuhlen, E \& Kortmann B (eds). Cause, Condition, Concession, Contrast: Cognitive and Discourse Perspectives. Berlin: Mouton / De Gruyter, 342-360.

Korpel, M C A \& de Moor, J C 1988. Fundamentals of Ugaritic and Hebrew Poetry, in: Van der Meer, W \& de Moor, J C (eds). The Structural Analysis of Biblical and Canaanite Poetry (JSOTS 74). Sheffield: Sheffield Academic Press, 1-61.

Krebernik, M 1984. Die Beschwörungen aus Fara und Ebla: Untersuchungen zur ältesten keilschriftlichen Beschwörungsliteratur. Hildesheim: Georg Olms Verlag.

KUB = Figulla, H H et al. (eds) 1921-. Keilschrifturkunden aus Boghasköi. Berlin: Staatliche Museen.

Kugel, J L 1998. The Idea of Biblical Poetry: Parallelism and its History. New Haven: Yale University Press.

$\mathrm{KTU}^{3}=$ Dietrich, M, Loretz, O \& Sanmartín, J (eds) 2013. Die keilalphabetischen Texte aus Ugarit, Ras Ibn Hani und anderen Orten / The Cuneiform Alphabetic Texts from Ugarit, Ras Ibn Hani, and Other Places. 3rd enlarged ed. (AOAT 360/1). Münster: Ugarit-Verlag.

Leitz, C 1996. Die Schlangensprüche in den Pyramidentexten. Orientalia 65, 381-427. 
Mathieu, B 2002. Les formules conjuratoires dans les pyramides à textes: quelques réflexions, in: Koenig, Y (ed.). La magie en Égypte: À la recherche d'un définition. Paris: La documentation française, 185-206.

Meurer, G 2002. Die Feinde des Königs in den Pyramidentexten (OBO 189). Freiburg / Göttingen: Universitätsverlag / Vandenhoeck \& Ruprecht.

Morgenstern, M 2012. Review: Richard C. Steiner, Early Northwest Semitic Serpent Spells in the Pyramid Texts. JSS 57/2, 450-451.

Moyer, J C 1981. Hittite and Israelite Cultic Practices: A Selected Comparison, in: Hallo W W, Moger, J C \& Perdue, L G (eds). Scripture in Context II: More Essays on the Comparative Method. Winona Lake: Eisenbrauns, 19-38.

Neef, H-D 1999. Vom Gottesgericht zum universalen Heil. Komposition und Redaktion des Zephanjabuches. ZAW 111, 530-546.

Nel, P J 1989. Structural and Conceptual Strategy in Zephaniah, Chapter 1. JNSL 15, 155-167.

Nims, C F \& Steiner R C 1983. A Paganized Version of Ps 20:2-6 from the Aramaic Text in Demotic Script. JAOS 103, 261-74.

Norin, S I L 2002. Baal, Kinderopfer und „über die Schwelle springen“, Propheten und israelitische Religion im siebten Jahrhundert v.Chr., in: Irsigler, H \& Ólason K (eds). ,, Wer darf hinaufsteigen zum Berg JHWHs? “: Beiträge zu Prophetie und Poesie des Alten Testaments: Festschrift für Sigurdur Örn Steingrimsson zum 70. Geburtstag (ATSAT 72). St. Ottilien: EOS-Verlag, 75-100.

Porter, J R 1993. Thresholds in the Old Testament, in: Davidson, H E (ed.). Boundaries and Thresholds: Papers from a Colloquium of the Katherine Briggs Club. Gloucestershire: Thimble Press, 65-75.

Robertson, O P 1990. The Books of Nahum, Habakkuk, and Zephaniah (NICOT). Grand Rapids: Eerdmans.

Sabottka, L 1971. Zephanja. Versuch einer Neuübersetzung mit philologischem Kommentar (Biblica et Orientalia 25). Roma: Biblical Institute Press.

Schearing L S \& McKenzie, S L (eds) 1999. Those Elusive Deuteronomists (JSOTSup 268). Sheffield: Sheffield Academic Press.

Schroer, S 1987. In Israel gab es Bilder: Nachrichten von darstellender Kunst im Alten Testament (OBO 74). Freiburg / Göttingen: Universitätsverlag / Vandenhoeck \& Ruprecht.

Seybold, K 1985. Satirische Prophetie: Studien zum Buch Zefanja (SBS 120). Stuttgart: Katholisches Bibelwerk. 
Sethe, K 1908. Die altägyptischen Pyramidentexte nach den Papierabdrücken und Photographien des Berliner Museums. Leipzig: Hinrichs'sche Buchhandlung.

Snyman, S D 2000. Violence and Deceit in Zephaniah 1:9. OTE 13, 89-102.

Steiner, R C 2001. The Scorpion Spell from Wadi Hammamat: Another Aramaic Text in Demotic Script. JNES 60, 259-268.

Steiner, R C 2011. Early Northwest Semitic Serpent Spells in the Pyramid Texts (Harvard Semitic Series 61). Winona Lake: Eisenbrauns.

Sweeney, M A 2003. Zephaniah: A Commentary (Hermeneia). Minneapolis: Fortress Press.

Tobin, V A 1993. Divine Conflict in the Pyramid Texts. Journal of the American Research Center in Egypt 30, 93-110.

Tsumura D T 2009. Vertical Grammar of Parallelism in Hebrew Poetry. JBL 128, 167181.

Turner V 1967. The Forest of Symbols. Ithaca: Cornell University Press.

Udoekpo, M U 2010. Re-thinking the Day of YHWH and Restoration of Fortunes in the Prophet Zephaniah: An Exegetical and Theological Study of 1:14-18; 3:14-20 (Das Alte Testament in Dialog 2). Bern: Peter Lang.

Uehlinger, C 1996. Astralkultpriester und Fremdgekleidete, Kanaanvolk und Silberwäger: zur Verknüpfung von Kult- und Sozialkritik in Zef 1, in: Dietrich, W \& Schwantes M (eds). Der Tag wird kommen: Ein interkontextuelles Gespräch über das Buch des Propheten Zefanja (SBS 170). Stuttgart: Katholisches Bibelwerk, 49-83.

Van der Woude, A S 1978. Habakuk Zefanja (POT). Nijkerk: Callenbach.

Van Gennep, A 1909. Les rites de passage. Paris: Picard.

Van Wolde. E J 2010. Reframing Biblical Studies: When Language and Text Meet Culture, Cognition, and Context. Winona Lake: Eisenbrauns.

Verdonk, P 2005. Painting, Poetry, Parallelism: Ekphrasis, Stylistics and Cognitive Poetics. Language and Literature 14, 231-244.

Vlaardingerbroek, J 1999. Zephaniah (HCOT). Leuven: Peeters.

Watson, W G E 1984. Classical Hebrew Poetry: A Guide to Its Techniques (JSOTSup 26). Sheffield: Sheffield University Press.

Winckler, H 1905. Altorientalische Forschungen Vol. III/2. Leipzig: Eduard Pfeiffer. 
Wöhrle, J 2006. Die frühen Sammlungen des Zwölfprophetenbuches: Entstehung und Komposition (BZAW 360). Berlin: De Gruyter.

Zwickel, W 1973. סף Iפתן. BN 70, 25-27. 